\title{
Myles Coverdale as a New Source for the Matthew Bible Notes
}

Myles Coverdale was among the leading contributors to the first modern English translations of the Bible, and his lasting influence on early modern Bibles is widely known; however, his influence on these Bibles' paratexts has not been acknowledged. I have found that many of the 1537 Matthew Bible summaries derive from the 1535 Coverdale Bible. ${ }^{1}$

Editor John Rogers provided little in the way of original translation to the Matthew Bible, but he did include voluminous notes. These notes included prefatory material, a table of principal matters, glosses, summaries, and indices. Many of these are borrowed from French Bibles, the 1534 Lefèvre and 1535 Olivétan, ${ }^{2}$ and most notably the table of principal matters which is translated almost verbatim from Thomas Malingre's (also known by the anagrammatic pseudonym Mattheu Gramelin) 'Indice des principales matieres' ${ }^{3}$ Among this paratextual material are the casus summarii, chapter summaries that precede each chapter of the Bible. These have long been assumed to also have been largely or entirely translated from the Lefèvre Bible; ${ }^{4}$ however, a second major source is the 1535 Coverdale Bible. Elements of

\footnotetext{
${ }^{1} 1535$ Coverdale Bible, Biblia: The Byble: that is the holy Scrypture of the Olde and New Testament ([Cologne or Marburg]: 1535); The Matthew Bible, The Byble: which is all the holy Scripture: in whych are contayned the Olde and Newe Testament (Antwerp[?]: 1537).

${ }^{2}$ La saincte Bible en Francoys ([Antwerp]: 1534); La Bible ([Neuchâtel]: 1535).

${ }^{3}$ La saincte Bible, [prefatory material], fol. B1r; The Byble, [prefatory material] (1537), fol. $2 \mathrm{r}$.

${ }^{4}$ See Femke Molekamp, 'Genevan legacies: The Making of the English Geneva Bible', The Oxford Handbook of the Bible in Early Modern England, c. 1530 - 1700, ed. Kevin Killeen, Helen Smith, and Rachel Judith Willie (Oxford: Oxford University Press, 2015), 42; Vivienne Westbrook, Long Travail and Great Paynes: A Politics of Reformation Revision (Boston: Kluwer Academic, 2001), 41; Frederick Fyvie Bruce, History of the Bible in English, 3rd ed. (Guildford: Lutterworth Press, 1979), 66; Ariel Hessayon, 'The Apocrypha
} 
these paratexts were copied into the Great and Bishops' Bibles, and so their source is of interest to furthering the knowledge of sixteenth century biblical history.

In the New Testament of the Matthew Bible, the summaries are lifted directly from Coverdale's 1535 Bible. In Coverdale's Bible, this material does not appear as prefatory summaries before each chapter but rather a single self-contained contents list at the beginning of each book, denoting 'What [book] conteyneth'. These are lifted almost verbatim, with little to no alteration on Rogers' part and no mediation with the French sources. For comparison, here are the opening summaries to the gospels in Coverdale and the Matthew Bible. For Matthew 1:1, 'The genealogy of Christ, and mariage of his mother Mary. The angell satisfieth Josephs mynde' (Coverdale; Biblia, 'The New Testament', fol. A1v); 'The genealogye of Christ / \& maryage of his mother Mary. The angell satisfieth Josephs mynde' (Matthew; The Byble (1537), 'The Newe Testament', fol. A2r). For Mark 1:1, 'The office of Jhon the Baptist. The baptyme of Christ, his fastynge, his preachinge, and the callynge of Peter, Andrew, James and Jhon. Christ healeth the man with the uncleane sprete, helpeth Peters mother in lawe, and clenseth the leper' (Coverdale; Biblia, 'The New Testament', fol. C3v); 'The office of Jhon the Baptist. The baptyme of Christ / his fastinge / his preachinge / and the callynge of Peter, Andrew / James \& Jhon. Christ healeth the ma[n] wyth the uncleane sprete / helpeth Peters mother in lawe, and clenseth the leper' (Matthew; The Byble (1537), 'The Newe Testament', fol. B6v). For Luke 1:1, 'The co[n]cepcion and byrth of Jhon the Baptist. The concepcion of Christ. The thankfull songes of Mary, and Zachary’

in Early Modern England', The Oxford Handbook of the Bible in Early Modern England, c. 1530 - 1700, ed. Kevin Killeen, Helen Smith, and Rachel Judith Willie (Oxford: Oxford University Press, 2015), 136-7; David Daniell, 'Rogers, John (c. 1500-1555), Biblical Editor and Martyr', Oxford Dictionary of National Biography; S. L. Greenslade, 'English Versions of the Bible', The Cambridge History of the Bible: The West from the Reformation to the Present Day, ed. S. L. Greenslade (Cambridge: Cambridge University Press, 1975), 151. One exception is James Frederic Mozley, who notes Coverdale provides the source for the summaries to Revelations, but Mozley makes this observation only of Revelations and not the Old Testament as a whole; James Frederic Mozley, Coverdale and His Bibles (London: Lutterworth Press, 1953), 145-6. 
(Coverdale; Biblia, 'The New Testament', fol. D6v); 'The co[n]cepcion and byrth of John the Baptist. The co[n]cepion of Christe. The thankfull songes of Mary and Zachary' (Matthew; The Byble (1537), 'The Newe Testament', fol. C6v). For John 1:1, 'The euerlastinge byrth of the sonne of God, and how he became man. The testimony of Jhon and of his baptyme. The callinge of Andrew, Peter, Philip and Nathanael' (Coverdale; Biblia, 'The New Testament', fol. G4v); 'The euerlastung byrth of Chryst / and how he became man. The testimony of Jhon. The callynge of Andrew / Peter \& c.' (Matthew; The Byble (1537), 'The Newe Testament', fol. E4v). The Matthew Bible summaries are almost identical to those authored by Coverdale. While Rogers deviates in spelling and collapses Philip and Nathaniel into an 'et cetera', these summaries are otherwise entirely faithful to Coverdale.

In the Old Testament, Rogers does not lift from Coverdale directly. Many of these summaries are translations from the French, as is known, but they are not direct translations and do in fact mediate with Coverdale's Old Testament summaries. Whereas Rogers' translation of the table of principle matters is almost entirely verbatim, allowing for discrepancies between French and English grammar and the necessary alphabetical reordering, the Old Testament summaries are often significant departures. Sometimes Rogers lifts almost directly from the French, as in the case of Genesis 3: 'Comment le serpent seduist lhome: dont lhome est mauldict:mais la semence est promise/qui est Christ' is rendered as 'The serpent deceaveth the woman. The serpe[n]t the woman \& the man are cursed / and dryven out of Paradise. Christ oure sauvour is promised' (La saincte Bible, [Old Testament], fol. A1v; The Byble (1537), [Old Testament], fol. A1v). Rogers adds the point about being driven from paradise, but his translation is otherwise faithful. It is worth noting the French focuses entirely on man, l'homme, whereas Rogers has it explicitly be the woman who is deceived. This provides an instance in which Rogers derives his summaries from Lefèvre, as scholars have discussed; elsewhere, however, he constructs the Matthew Bible summaries 
from a combination of Lefèvre's French summaries and Coverdale's prefatory contents lists. For example, Genesis 12, which in the French is given as, 'Lobedience de Abram/\& la promesse faicte a luy mesme:la fuyte de Abram en Egipte a cause de la famine:\&sut issec la femme rauie pour le Roy' (La saincte Bible, [Old Testament], fol. A4v). In Matthew, the passage is summarised as the following: 'Abram is blessed of God/and goeth with Lot into a straunge lande that apered to him in Canaan. And God promyseth to geue the same lande to hym and to his sede. And after warde goeth Abram into Egypt \& causeth Sarai his wyfe to saye that she is his syster. And she was rauyshed of Pharao / for whyche the Lorde plageth hym' (The Byble (1537), [Old Testament], fol. A4v). There is nothing here of the French, save the reference to God's promise. If we turn to Coverdale, then the source of this summary is obvious: 'Abram goeth with Loth into a straunge londe at the worde of the Lord: which appeareth unto hym in Canaan: and promiseth to geue the same londe unto his sede: Afterwarde goeth Abram into Egypte and fayneth Saray to be his syster' (Biblia, [prefatory matter], fol. $8 \mathrm{v}$ ). Though not identical, as they are in the New Testament, Coverdale's influence on Rogers is clear. These influences are clear throughout the Old Testament, though see Genesis 3, Genesis 9, Exodus 3, Leviticus 1, and Leviticus 8 for especially obvious examples.

Rogers' use of Coverdale's summaries is undeniable, and Coverdale retained many of his own summaries when compiling the Great Bible in 1539, itself being a revision of the Matthew. Both Coverdale and Rogers need acknowledging for their paratextual contributions to English Bibles, many of which were retained into the Bishops' Bible and so continued to circulate into the seventeenth century. ${ }^{5}$

EZRA HORBURY University of Cambridge

\footnotetext{
${ }^{5}$ Daniell, Bible in English, 346.
} 